\title{
AN EXAMPLE OF REPARATORY SURFACE WELDING OF THE MINING MACHINE VITAL PART
} \author{
Nada Ilicí ${ }^{3}$ Branislav Hadzima ${ }^{2}$ \\ ${ }^{1}$ Faculty of Engineering, Kragujevac, Serbia \\ ${ }^{2}$ Research Center, University of Zilina, Zilina, Slovakia \\ ${ }^{3}$ Military Technical Institute, Belgrade, Serbia \\ *E-mail of corresponding author: ruzicarnikolic@yahoo.com
}

Dušan Arsić ${ }^{1}$, Ružica Nikolićc ${ }^{2, *}$, Vukić Lazić1, Srbislav Aleksandrović1, Ljubica Radović3

\section{Resume}

Mining machines' components, or the whole structure, are prone to frequent premature damages and fractures what is explained either by inadequate design and construction or by insufficient knowledge of the material's and welded joints' properties and oversights in manufacturing. Here is considered the bucket-wheel excavator, i.e. the fracture of the tooth of the girth gear, which enables the circular motion of the excavator's upper structure (which was in operation for 5000 hours). The gear was made of the cast steel GS $40 \mathrm{MnCrSi} 3$ V. The reparatory hard-facing (HF) technology of the fractured tooth required specification of numerous operations including the preparation works. The reparation realized the two-fold savings, in time and money - the new girth gear costs over $500000 €$ and its manufacturing lasts 6 to 9 months, while the safety and quality of the repaired tooth was guaranteed.

\section{Article info}

Received 7 May 2020

Accepted 7 July 2020

Online 19 November 2020

\section{Keywords:}

bucket-wheel excavator, girth gear, tooth fracture, reparatory surface welding, financial gains

ISSN 1335-4205 (print version) ISSN 2585-7878 (online version)

\section{Introduction}

The Bucket wheel excavators (BWE) are in exploitation subjected to stresses that appear in manufacturing of parts and mounting of equipment (residual stresses), as well as during their functioning (stationary and dynamic loadings) and during the disrupted exploitation (nonstationary dynamic loadings) [1-2]. Thus, the loading of the bucket wheel excavators' parts and assemblies cannot be formulated by a simple form mathematical function. That loading cannot be represented by a model where the variables and/or parameters would be uniformly varying in the working conditions, for a model like that would have to include a series of approximations resulting from the real exploitation conditions [1]. Those are the reasons why only testing of a BWE in the real working conditions would make possible to completely estimate its state and to obtain all the data necessary for comparing the quality of the machine and its structure and for estimating the influence of the working environment on the carrying capacity of its parts and assemblies. Numerous failures of the BWE structures are presented in papers [3-8] and of similar structures in papers [9-18]. It should be emphasized that the presented procedure can successfully be applied to other machine parts and technical systems, like: transport mechanisms [12], parts of boilers [13-14], forging dies [15-16], stone crushers' mills and parts of the construction mechanization [17], turbine elements etc. In addition, each executed reparation requires prior extensive preparation procedure, which would enable successful execution of the reparation itself [18].

The bucket wheel excavator TAKRAF SRs $2000 \times 32 / 5.0$ [19], which operates at the open pit mine "Kostolac" (Serbia), is shown in Figure 1 and its basic technotechnological characteristics are given in Table 1. It was employed on excavation of the barren soil for $5.000 \mathrm{~h}$ (a few weeks more than a year after the assembly) when the fracture of the tooth of the girth gear, which enables the circular motion of the upper structure of the bucket-wheel excavator, occurred.

It was established, through analysis of the fracture surface that the fracture occurred during the fatigue loading and due to existence of an initial crack in the tooth base. That crack was created during the girth gear manufacturing and it was not detected prior to gear's mounting onto the BWE's structure.

In Figures 2 to 4 are shown the gear, the broken tooth and the girth gear fracture surface, respectively. Analysis of the broken tooth fracture surface clearly shows that the very small portion of the tooth was loaded in fatigue (smooth fracture surface of the girth gear) and that the much larger portion was subjected to static fracture (the rough fracture surface of the girth gear), Figure 4 .

According to the manufacturer's documentation, the girth gear was made of the cast steel GS $40 \mathrm{MnCrSi3} \mathrm{V}$ [19]. 


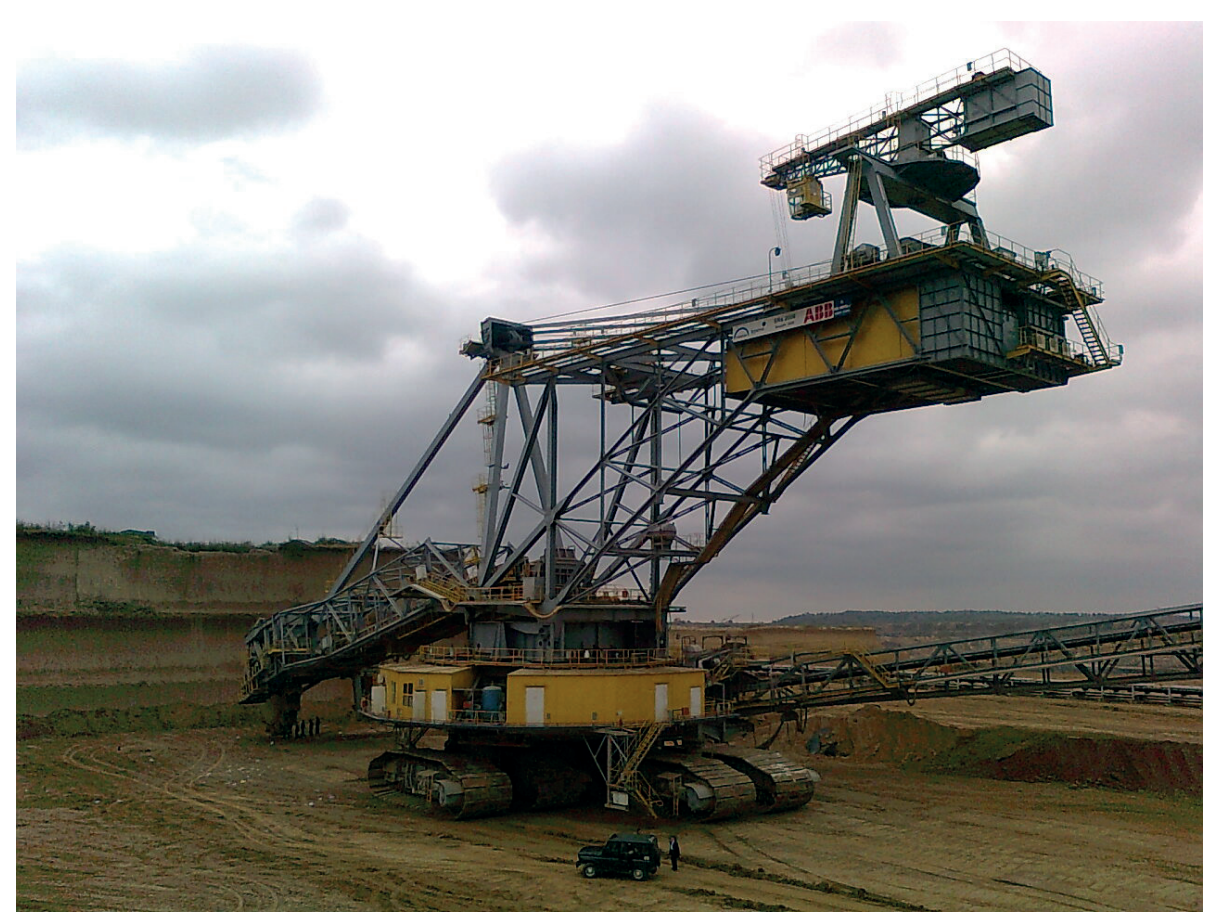

Figure 1 Bucket wheel excavator SRs 2000×32/5.0

Table 1 Basic technical characteristics of the bucket wheel excavator TAKRAF SRs 2000×32/5.0

\begin{tabular}{|c|c|}
\hline characteristics & notation/units \\
\hline volume of a bucket with a ring space & $\mathrm{W}_{\text {buck }}=2000\left(\mathrm{~m}^{3}\right)$ \\
\hline maximum cut height & $\mathrm{H}=32(\mathrm{~m})$ \\
\hline maximum cut depth & $\mathrm{L}=5(\mathrm{~m})$ \\
\hline diameter of the rotor wheel & $\mathrm{D}_{\mathrm{r}}=12(\mathrm{~m})$ \\
\hline number of buckets & $\mathrm{z}=20$ \\
\hline installed engine power for rotor drive $(2 \times 670 \mathrm{~kW})$ & $\mathrm{N}=1340(\mathrm{~kW})$ \\
\hline motor voltage & $6000(\mathrm{~V})$ \\
\hline specific resistance to excavation per knife length & $\mathrm{k}_{\mathrm{L}}=100(\mathrm{~N} / \mathrm{mm})$ \\
\hline speed of the upper construction & $30(\mathrm{~m} / \mathrm{min})$ \\
\hline peripheral speed of the rotor wheel & $2.7(\mathrm{~m} / \mathrm{s})$ \\
\hline teeth number of the pinion for rotation of the excavator's upper structure & $\mathrm{z}_{\mathrm{p}}=16$ \\
\hline $\begin{array}{l}\text { teeth number of the girth gear for rotation of the excavators' upper } \\
\text { structure }\end{array}$ & $\mathrm{z}_{\mathrm{gg}}=312$ \\
\hline teeth module of the pinion for rotation of the excavator's upper structure & $\mathrm{m}=36$ \\
\hline outside diameter of girth gear & $\mathrm{D}_{\mathrm{gg}}=11232(\mathrm{~mm})$ \\
\hline outside diameter of the pinion & $\mathrm{D}_{\mathrm{p}}=576(\mathrm{~mm})$ \\
\hline output rpm on the pinion & $\mathrm{N}_{\mathrm{p}}=2.28(\mathrm{rpm})$ \\
\hline Rpm of the girth gear rotation & $\mathrm{N}_{\mathrm{gg}}=0.12(\mathrm{rpm})$ \\
\hline
\end{tabular}

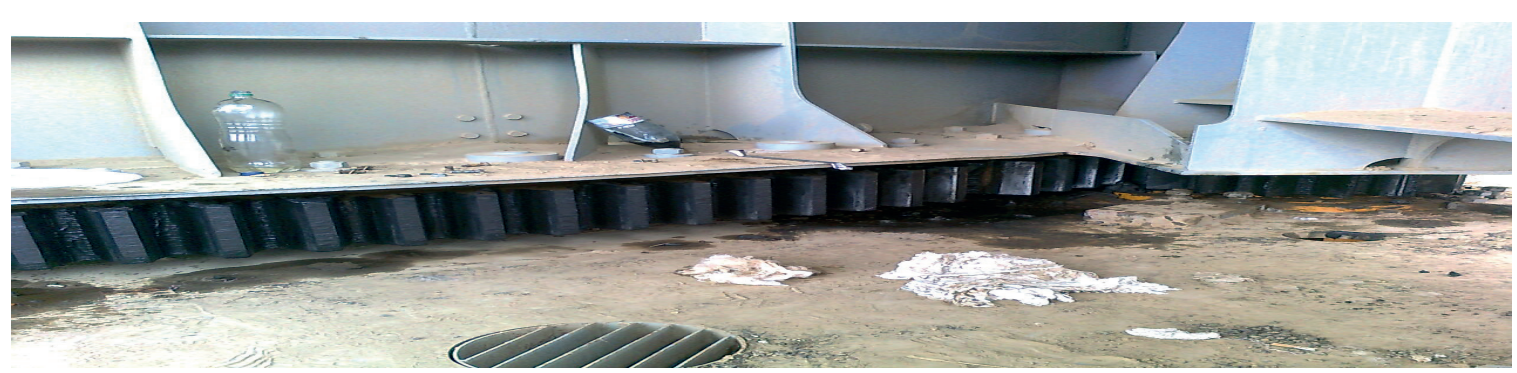

Figure 2 Appearance of the girth gear and the pinion for rotation of the excavator's upper structure 

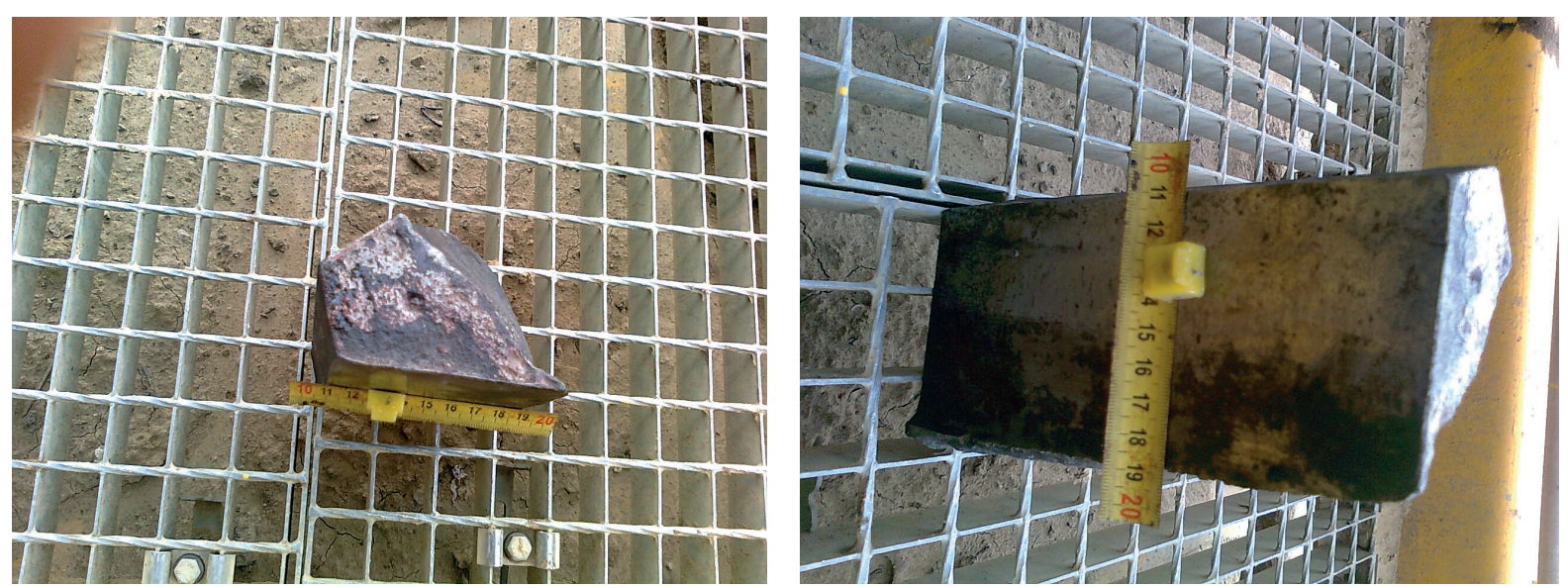

Figure 3 Appearance of the broken tooth and its dimensions

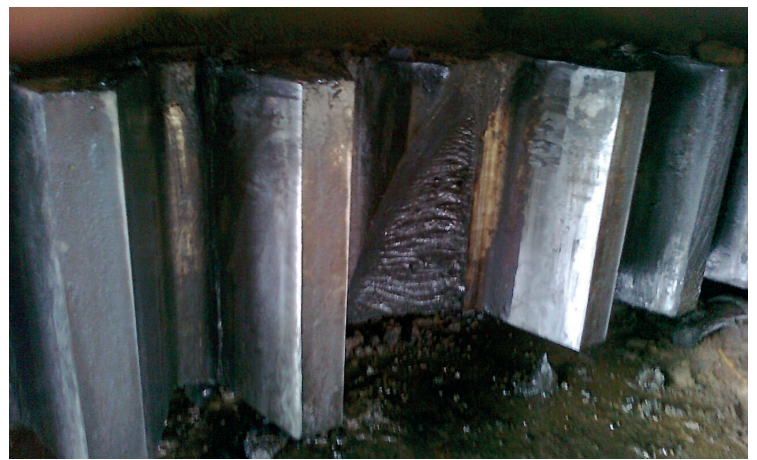

Figure 4 Appearance of the girth gear fracture surface at the broken tooth spot

Table 2 Chemical composition of the cast steel GS $40 \mathrm{MnCrSi3}$ V, values in \%

\begin{tabular}{ccccccc}
\hline $\mathrm{C}$ & $\mathrm{Si}$ & $\mathrm{Mn}$ & $\mathrm{Cr}$ & $\mathrm{P}$ & $\mathrm{S}$ & $\mathrm{Cu}$ \\
\hline $0.35-0.45$ & $0.50-0.75$ & $0.60-0.90$ & $0.50-0.80$ & $\leq 0.040$ & $\leq 0.040$ & $\leq 0.30$ \\
\hline
\end{tabular}

Table 3 Mechanical properties of the cast steel GS $40 \mathrm{MnCrSi3} \mathrm{V}$

\begin{tabular}{ccccc}
\hline yield stress & tensile strength & elongation & impact energy & contraction Z (\%) \\
$\mathrm{R}_{0.2}\left(\mathrm{~N} / \mathrm{mm}^{2}\right)$ & $\mathrm{R}_{\mathrm{m}}\left(\mathrm{N} / \mathrm{mm}^{2}\right)$ & $\mathrm{A} 5(\%)$ & $\mathrm{KCU} 3\left(\mathrm{~J} / \mathrm{cm}^{2}\right)$ & 20 \\
\hline 390 & 740 & 10 & $\min 24$ & 24 \\
\hline
\end{tabular}

Its chemical composition and mechanical properties are given in Tables 2 and 3, respectively.

To predict the cast steel GS $40 \mathrm{MnCrSi3}$ V resistance to crack propagation, the fracture parameters were calculated, namely the critical value of the stress intensity factor - the facture toughness $K_{I c}$ and the critical crack length $a_{c r}$, based on the obtained values of the material's impact energy and the yield stress, according to the Barsom-Rolfe model [20]. The calculated value of the critical crack length was $61.9 \mathrm{~mm}$. The detailed procedure for calculation of given parameter is presented in [21-22].

\section{Methodology of the new tooth manufacturing by the reparatory hard-facing}

Due to the complex construction solution of the girth gear and its function in exploitation, it was necessary to precisely define a large number of details and carefully consider and execute all the operations in the methodology of manufacturing the new tooth. This was an imperative in order to ensure the safety of the repaired girth gear exploitation, since the smallest oversight, underestimate or improper execution could cause serious problems in the operation of the BWE as a whole. This is the reason why the preparation procedure for the hard-facing technology is presented, as well.

\subsection{Analysis of the girth gear material's weldability}

According to equivalent carbon formula - Equation (1) - of the International Welding Institute [23], the limiting value for the good weldability of this material should not be greater than 0.45 . For the maximal values of the chemical elements composition of the GS 40 


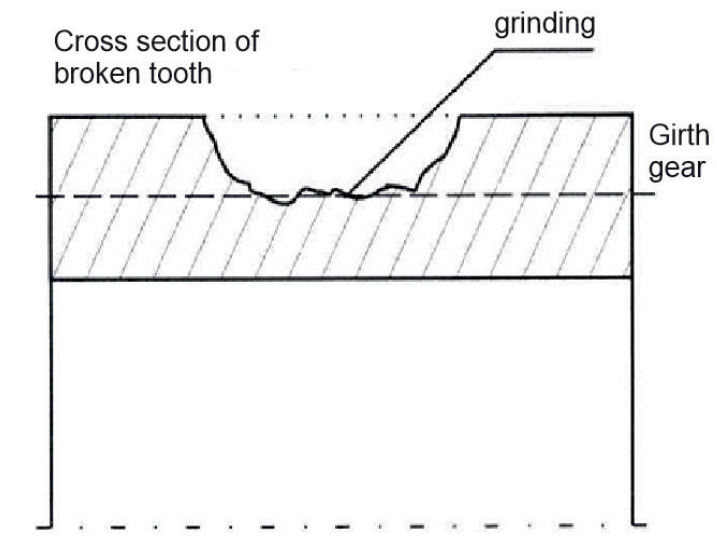

Figure 5 Schematic presentation of the girth gear cross section at the broken tooth spot

MnCrSi3 V, given in Table 1 , that value is 0.57 . The value obtained by the Ito-Bessyo formula - Equation (2) - of 0.68 , also surpasses the limiting value for the good weldability of 0.30 [24]. The presented data point to the fact that this steel is prone to cold cracks appearance, what prompted the necessity for the hard-facing of the broken tooth to be performed with preheating and controlled cooling.

$$
\begin{aligned}
C E V & =C+\frac{M n}{6}+\frac{C r+M o+V}{5}+\frac{N i+C u}{15} . \\
C E V & =C+\frac{S i}{30}+\frac{M n+C u+C r}{20}+ \\
& +\frac{M o}{15}+\frac{N i}{60}+\frac{V}{10} .
\end{aligned}
$$

According to Equation (3) for the Hot Cracking Susceptibility (or Sensitivity) (HCS) [23], it was established that this material is prone to appearance of the hot cracks, as well, since the obtained value for HCS was 21.52, which is greater than 4 - the limiting value for this type of steels with tensile strength of about $700 \mathrm{~N} / \mathrm{mm}^{2}$.

$$
H S C=\frac{C \cdot\left(S+P+\frac{S i}{25}+\frac{N i}{100}\right) \cdot 10^{3}}{3 \cdot M n+C r+M o+V} .
$$

Due to the girth gear construction (dimensions and mass) and conditions of the hard-facing execution without the heat treatment, for the filling volume greater than 500 $\mathrm{cm}^{3}$, the recommended preheating temperature is within range $100{ }^{\circ} \mathrm{C}$ to $150{ }^{\circ} \mathrm{C}$. The preheating temperature was determined according to Seferian's formula [25-26].

\subsection{Preparation operations for the reparatory hard-facing of the girth gear tooth}

The hard-facing preparation procedure included the following operations:

- Providing the means of protection at work

- Preparing the copper templates for various purposes and corresponding geometries
- The first measurement of the girth gear deformation (planarity test) by the appropriate template (measures' controller)

- Grinding of the fracture surface of the girth gear in the zone of the broken tooth by the corresponding grinders until the complete removal of all the unevenness and cracks, Figure 5

- Cleaning of surfaces prepared for welding the new tooth of the anti-corrosion protection (ACP) and the corrosion products

- Shaping the ground pieces, in order to remove the sharp edges, for welding of the new tooth

- Processing of ground pieces with brushless sand papers to provide the necessary quality of surfaces for testing by the non-destruction methods

- Testing of the ground pieces by magnetic particles [27-28] and penetrants [29-30]

- Precise definition (by adequate template) of the position, width, length, depth and volume of the ground places

- Providing that the ground surfaces are degreased, clean and dry

- Placing the adequate templates at the position of the tooth hard-facing

\subsection{Order of operations of the girth gear tooth reparatory hard-facing}

Reparatory hard-facing included the following operations:

- Placing the corresponding references for control of the girth gear deformation (planarity test)

- Depositing of the I (first - initial) hard-facing layer at the ground spot by austenitic filler metal with forging by the round tip pneumatic hammer of $3 \mathrm{~mm}$ diameter

- Shaping of the I hard-faced layer of the new tooth by adequate template, with respect to the base material plane (Figure 6) with overfill of order 0.2 to $0.3 \mathrm{~mm}$

- Repeating of the welding if the non-destructive test showed necessity for it 


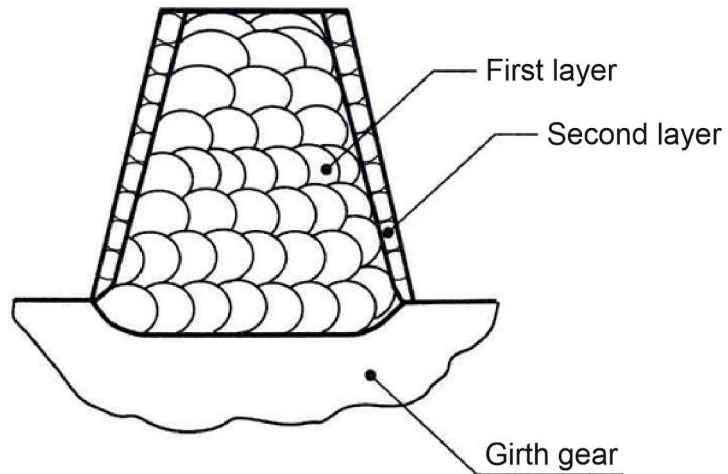

(a)

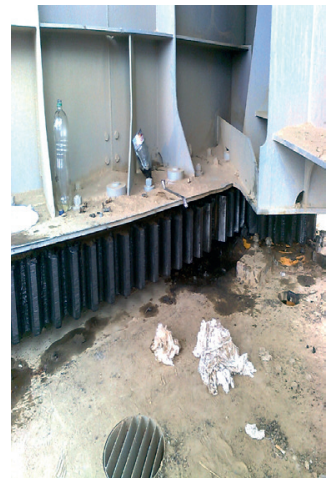

(b)

Figure 6 Order of the hard-facing layers deposition (a) and appearance of the new tooth (b)

Table 4 Chemical composition of the E 18 8Mn B 22 electrode, values in [\%]

\begin{tabular}{ccccc}
\hline $\mathrm{C}$ & $\mathrm{Si}$ & $\mathrm{Mn}$ & $\mathrm{Ni}$ & $\mathrm{Cr}$ \\
\hline 0.12 & 0.80 & 7.00 & 9.00 & 18.00 \\
\hline
\end{tabular}

Table 5 Mechanical properties of the pure weld metal

\begin{tabular}{cccc}
\hline yield stress & tensile strength & elongation \\
$\mathrm{Rp} 0.2 \%\left(\mathrm{~N} / \mathrm{mm}^{2}\right)$ & $\mathrm{R}_{\mathrm{m}}\left(\mathrm{N} / \mathrm{mm}^{2}\right)$ & $\mathrm{A} 5(\%)$ & toughness \\
$\mathrm{A}$ & $590-690$ & $>40$ & $\mathrm{Av}(\mathrm{J})$ \\
\hline
\end{tabular}

Table 6 Chemical composition of the E 1-UM-300 electrode, values in [\%] and hardness

\begin{tabular}{cccc}
\hline $\mathrm{C}$ & $\mathrm{Mn}$ & $\mathrm{Ni}$ & Hardness (HB) \\
\hline 0.18 & 1.3 & 1.2 & $280-330$ \\
\hline
\end{tabular}

- $\quad$ Testing of the I layer with respect to the base metal (BM) plane by magnetic particles [27-28] and penetrants [29-30]

- $\quad$ Processing of surfaces by the sand paper in the zones of the new tooth welding up to reaching the machining quality of $\mathrm{Ra}_{\max }=1.6 \mu \mathrm{m}$ (permissible overfill and underfill up to $0.03 \mathrm{~mm}$ )

- In the case of the satisfying tests results, after each layer deposition, forging of ground surfaces by the round tip pneumatic hammer of $3 \mathrm{~mm}$ diameter for the purpose of reducing the residual stresses in the weld metal (WM) and the heat affected zone (HAZ)

- Control of the filler metal, welding parameters and deposited layers dimensions during the welding

- Depositing of the II (second - final) layer of the new tooth by the basic filler metal with forging by the round tip pneumatic hammer of $3 \mathrm{~mm}$ diameter

- Final measurement of the girth gear deformation (planarity test) by the appropriate template (measures controller)

- Final testing of the new tooth by magnetic particles and penetrants [27-30]

- Manual machining of the girth gear in the case of unsatisfactory planarity.

The order of the hard-facing layers deposition and appearance of the new tooth are shown in Figure 6.

\subsection{Technology of the girth gear tooth reparatory hard-facing}

This hard-facing technology is completely defined by the presented preparatory and depositing operations. Depositing of the I layer was executed by the austenitic electrode marked E 18 8Mn B 22 [31], while the II layer was deposited by the basic electrode marked $\mathrm{E}$ 1-UM-300 (DIN 8555) [32]. The chemical composition of the E 18 8Mn B 22 electrode is presented in Table 4, mechanical properties of the weld metal in Table 5 and the chemical composition of the E 1-UM-300 electrode in Table 6.

\section{Conclusions}

Reparation of the girth gear tooth of the bucket wheel excavator SRs $2000 \times 32 / 5.0$, by the presented methodology, was executed in 14 days in 2013. Considering that the excavator is still in operation at the open pit mine "Kostolac" (Serbia), it could be concluded that the reparation was successful.

It should be emphasized that in this way the large financial effect was realized since the construction of the new girth gear would cost over $500000 €$. If the time, needed 
for manufacturing the new girth gear, which is about 6 to 9 months, would also be included in this calculation, as well as effect of the electric power that would not be produced in such a long period, the total positive financial effect is about $8000000 €$.

The presented methodology of the reparatory hardfacing, as well as the welding procedure, can be applicable, with necessary adjustments, for recovery of other parts and structures of the bucket wheel excavator or other machines at open pit mines.

\section{Acknowledgment}

This research was partially financially supported by the project "Innovative Solutions for Propulsion, Power and Safety Components of Transport Vehicles" ITMS 313011V334 of the Operational Program Integrated Infrastructure 2014 2020 and co-funded by the European Regional Development Fund and projects TR35006 and TR35024 financed by the Ministry of education, science and technological development of Republic of Serbia.

\section{References}

[1] ARSIC, M., BOSNJAK, S., ZRNIC, N., SEDMAK, A., GNJATOVIC, N. Bucket wheel failure caused by residual stresses in welded joints. Engineering Failure Analysis [online]. 2011, 18(2), p. 700-712. ISSN 1350-6307. Available from: https://doi.org/10.1016/j.engfailanal.2010.11.009

[2] SEDMAK, S., SEDMAK, A., ARSIC, M., TUMA, J. V. An experimental verification of numerical models for the fracture and fatigue of welded structures. Materiali in Tehnologije - Materials and Technology. 2007, 41(4), p. 173-178. ISSN 1580-2949.

[3] DJURDJEVIC, D. J., MANESKI, T., MILOSEVIC, V., MITIC-ANDJELIC, N., IGNJATOVIC, D. Failure investigation and reparation of a crack on the boom of the bucket wheel excavator ERS 1250 Gacko. Engineering Failure Analysis [online]. 2018, 92, p. 301-316. ISSN 1350-6307. Available from: https://doi.org/10.1016/j.engfailanal.2018.05.015

[4] ZRNIC, N., BOSNJAK, S., GASIC, V., ARSIC, M., PETKOVIC, Z. Failure analysis of the tower crane counterjib. Procedia Engineering [online]. 2011, 10, p. 2238-2243. ISSN 1877-7058. Available from: https://doi.org/10.1016/j. proeng.2011.04.370

[5] SEDMAK, S., JOVICIC, R., SEDMAK, A., ARANDJELOVIC, M., DJORDJEVIC, B. Influence of multiple defects in welded joints subjected to fatigue loading according to SIST EN ISO 5817:2014. Structural Integrity and Life. 2018, 18(1), p. 77-81. ISSN 1451-3749, eISSN 1820-7863.

[6] ARSIC, M., BOSNJAK, S., ODANOVIC, Z., DUNJIC, M., SIMONOVIC, A. Analysis of the spreader track wheels premature damages. Engineering Failure Analysis [online]. 2012, 20(1), p. 118-136. ISSN 1350-6307. Available from: https://doi.org/10.1016/j.engfailanal.2011.11.005

[7] BOSNJAK, S., ARSIC, M., SAVICEVIC, S., MILOJEVIC, G., ARSIC, D. Fracture analysis of the pulley of a bucket wheel boom hoist system. Eksploatacja i Niezawodnosc - Maintenance and Reliability [online]. 2016, 18(2), 155-163. ISSN 15072711. Available from: https://doi.org/10.17531/ein.2016.2.1

[8] BOSNJAK, S., ARSIC, M., GNJATOVIC, N., MILENOVIC, I., ARSIC, D. Failure of the bucket wheel excavator bucket. Engineering Failure Analysis [online]. 2018, 84, p. 247-261. ISSN 1350-6307. Available from: https://doi.org/10.1016/j. engfailanal.2017.11.017

[9] LAZIC, V., SEDMAK, A., ALEKSANDROVIC, S., MILOSAVLJEVIC, D., CUKIC, R., GRABULOV, V. Reparation of damaged mallet for hammer forging by hard facing and weld cladding. Technical Gazette. 2009, 16(4), p. 07-113. ISSN 1330-3651.

[10] MEDJO, B., ARSIC, M., MLADENOVIC, M., SAVIC, Z., GRABULOV, V., RADOSAVLJEVIC, Z., RAKIN, M., Influence of defects on limit loads and integrity of the pipeline at hydropower plant "Pirot". Structural Integrity and Life. 2020, 20(1), p. 82-86. ISSN 1451-3749, eISSN 1820-7863.

[11] ARSIC, D., NIKOLIC, R., LAZIC, V., ARSIC, A., SAVIC, Z., DJACIC, S., HADZIMA, B. Analysis of the cause of the girth gear tooth fracture occurrence at the bucket wheel excavator. Transportation Research Procedia [online]. 2019, 40, p. 413-418. ISSN 2352-1465. Available from: https://doi.org/10.1016/j.trpro.2019.07.060

[12] TANASKOVIC, D., DJORDJEVIC, B., TATIC, U., SEDMAK, S., GAJIN, M. Cracking due to repair welding of the treiber roll. Structural Integrity and Life. 2017, 17(2), p. 133-138. ISSN 1451-3749, eISSN 1820-7863.

[13] TANASKOVIC, D., DJODRJEVIC, B., GAJIN, M., ARANĐElOVIC, M., GOSTOVIC, N., Damages of burner pipes due to the working conditions and its repair welding, Procedia Structural Integrity [online]. 2018, 13, p. 404-409. ISSN 2452-3216. Available from: https://doi.org/10.1016/j.prostr.2018.12.067

[14] MILOVANOVIC, N., DJORDJEVIC, B., TATIC, U., SEDMAK, S., STRBACKI, S. Low-temperature corrosion damage and repair of boiler bottom panel tubes. Structural Integrity and Life. 2017, 17(2), p. 125-131. ISSN 1451-3749, eISSN 1820-7863.

[15] ARSIC, D., LAZIC, V., SAMARDZIC, I., NIKOLIC, R., ALEKSANDROVIC, S., DJORDJEVIC, M., HADZIMA, B. Impact of the hard facing technology and the filler metal on tribological characteristics of the hard faced forging dies. Tehnicki Vjesnik - Technical Gazette [online]. 2015, 22(5), p. 1353-1358. ISSN 1330-3651, eISSN 1848-6339. Available from: https://doi.org/10.17559/TV-20150408152638 
[16] ARSIC, D., LAZIC, V., SEDMAK, A., NIKOLIC, R., ALEKSANDROVIC, S., DJORDJEVIC, M., BAKIC, R., SAMARDZIC, I. Selection of the optimal hard facing (HF) technology of damaged forging dies based on cooling time $t_{8 / 5}$. Metalurgija Metallurgy. 2016, 55(1), p. 103-106. ISSN 0543-5846.

[17] LAZIC, V., ARSIC, D., NIKOLIC, R., MUTAVDZIC, M., MESKO, J. Reparation by hard facing of the damaged secondary stone crushers. Manufacturing Technology [online]. 2016, 16(1), p. 375-380. ISSN 1213-2489. Available from: https://doi.org/10.21062/ujep/x.2016/a/1213-2489/MT/16/2/375

[18] LAZIC, V., CUKIC, R., ALEKSANDROVIC, S., MILOSAVLJEVIC, D., ARSIC, D., NEDELJKOVIC, B., DJORDJEVIC, M. Techno-economic justification of reparatory hard facing of various working parts of mechanical systems. Tribology in Industry [online]. 2014, 36(3), p. 287-292. ISSN 0354-8996, eISSN 2217-7965. Available from: http://www.tribology.rs/ journals/2014/2014-3/7.pdf

[19] TAKRAF, Gmbh. Bucket wheel excavator SRs 2000 in Serbia. Tenova, Germany, 2007.

[20] HERTZBERG, R. W. Deformation and fracture mechanics of engineering materials. John Wiley \& Sons, Inc., 1995. ISBN 13: 9780471012146

[21] ARSIC, D., GNJATOVIC, N., SEDMAK, S., ARSIC, A., UHRICIK, M. Integrity assessment and determination of residual fatigue life of vital parts of bucket-wheel excavator operating under dynamic loads. Engineering Failure Analysis [online]. 2019, 105 p. 182-195. ISSN 1350-6307. Available from: https://doi.org/10.1016/j.engfailanal.2019.06.072

[22] ARSIC, M., BOSNJAK, S., SEDMAK, S., VISTAC, B., SAVIC, Z., Repair of cracks detected in cast components of vertical Kaplan turbine rotor hub. Structural Integrity and Life. 2019, 19(3), p. 243-250. ISSN 1451-3749, eISSN 1820-7863.

[23] KARPICHEV, V., SERGEEV, K., BOLOTINA, A., Modeling of technological processes of machine-building and repair manufacture. Communications - Scientific Letters of the University of Zilina [online]. 2019, 21(4), p. 59-62. ISSN 1335-4205, eISSN 2585-7878. Available from: http://komunikacie.uniza.sk/index.php/communications/article/ view/1518

[24] ITO, Y., BESSYO, K. Weld crackability formula of high strength steels. Journal of Iron and Steel Research International. 1972, 13, p. 916-930. ISSN 1006-706X, eISSN 2210-3988.

[25] LAZIC, V., ALEKSANDROVIC, S., NIKOLIC, R., PROKIC-CVETKOVIC, R., POPOVIC, O., MILOSAVLJEVIC, D., CUKIC, R. Estimates of weldability and selection of optimal procedure for welding of high strength steel. Procedia Engineering [online]. 2012, 40, p. 310-315. ISSN 1877-7058. Available from: https://doi.org/10.1016/j.proeng.2012.07.100

[26] NEJKOVIC, V., MILICEVIC, M., RADAKOVIC, Z., New method for determining cooling time and preheating temperature in arc welding. Thermal Science [online]. 2019, 23(6), p. 3975-3984. ISSN 0354-9836, eISSN 2334-7163. Available from: https://doi.org/10.2298/TSCI180330297N

[27] ISO 17638:2016. Non-destructive testing of welds - magnetic particle testing. European Committee for Standardization, 2013.

[28] ISO 23278. Non-destructive testing of welds - magnetic particle testing of welds - acceptance levels. European Committee for Standardization, 2009.

[29] ISO 3452-1:2013. Non-destructive testing. Penetrant testing. Part 1: general principles. European Committee for Standardization, 2013.

[30] ISO 23277. Non-destructive testing of welds. Penetrant testing of welds. Acceptance levels. European Committee for Standardization, 2016.

[31] EN 1600: E 188 Mn B 22. Austenite basic electrode for welding of stainless Cr and CrNi steels. Classification, 1997.

[32] DIN 8555: E 1-UM-300. Basic electrode alloyed with $\mathrm{Cr}$ and Mn for medium hard surfacing. Classification, 1997. 